\title{
Chemical Composition and Biological Activity of the Essential Oils of Senecio aegyptius var. discoideus Boiss.
}

\author{
Assem El-Shazlya,b, Gamal DoraI ${ }^{\mathrm{a}}$ and Michael Wink ${ }^{\mathrm{b}, *}$ \\ a Department of Pharmacognosy, Faculty of Pharmacy, Zagazig University, Zagazig, Egypt \\ b Institut für Pharmazeutische Biologie, Im Neuenheimer Feld 364, 69120 Heidelberg, \\ Germany. Fax: +496221-544884. E-mail: wink@uni-hd.de \\ * Author for correspondence and reprint requests \\ Z. Naturforsch. 57c, 434-439 (2002); received January 9/February 1, 2002 \\ Senecio aegyptius var. discoideus, Compositae, GLC-Mass Spectrometry \\ The essential oil of Senecio aegyptius var. discoideus flowers, leaves, stems and roots \\ were isolated by hydrodistillation. Analysis of the oils by capillary GLC and GLC-mass \\ spectrometry were performed and 34 out of 37 compounds were identified. The main compo- \\ nent was isolated and characterized as 1,10-epoxyfuranoeremophilane using a combination \\ of GLC, GLC-MS, and NMR analyses. The oils of flowers, leaves and stems were rich in \\ monoterpene hydrocarbons while the root oil mainly contains furanoeremophilanes. Flower \\ and leaf volatile oils showed significant level of antifungal activity against C. albicans, moder- \\ ate effect against Gram positive bacteria, however, it has weak activity against Gram negative \\ bacteria. The isolated sesquiterpene (1,10-epoxyfuranoeremophilane) exhibited substantial \\ inhibitory activity against Gram negative bacteria.
}

\section{Introduction}

Senecio is the largest genus in the tribe Senecioneae (Asteraceae) and more than 1500 species have been reported (Nordenstam, 1977). This genus is rich in pyrrolizidine alkaloids (Rizk, 1990; Hartmann and Witte, 1995), and sesquiterpenes, in particular eremophilanolide derivatives (Bohlmann et al., 1977, 1979). Few reports about essential oil contents of members of this genus have been reported (Mitsuo et al., 1979; Van Dooren et al., 1981; De Pooter et al., 1986; Mangi et al., 1995; Grace and Khattab 1998; El-Shazly 1999).

We already studied the alkaloid composition of S. aegyptius var. discoideus from Egypt (El-Shazly, 2002). In this communication, we report on the volatile oil contents and composition of different plant organs of S. aegyptius var. discoideus. As far as we could investigate, such a study has not been undertaken before.

\section{Material and Methods}

\section{Plant material}

The plant material of $S$. aegyptius var. discoideus Boiss. was collected during flowering period from wild plants growing on Nile banks at the vicinity of
Benha (province Kalubeya) Egypt, in April 2000. Identification of the plant was confirmed by Dr. H. Abdel Baset, Faculty of Science, Zagazig University. A voucher specimen has been deposited at the Herbarium of the Department of Pharmacognosy, Faculty of Pharmacy, Zagazig University, Egypt.

\section{Essential oils isolation}

Fresh flowers, leaves, stems and roots were hydrodistilled for $4 \mathrm{~h}$ and the percentage of the oil for each organ was found to be $0.3,0.4,0.1$ and $0.05 \mathrm{v} / \mathrm{w}$ yield, respectively according to Egyptian Pharmacopoeia 1984. The oils were dried over anhydrous sodium sulphate and kept at $4{ }^{\circ} \mathrm{C}$ in sealed brown vials for analysis.

\section{Isolation of major component}

The major component (35) was isolated as a colourless oil by PLC [silica gel $\mathrm{F}_{254}, n$-hexane methanol, $9: 1]$ from the hydrodistilled oil obtained from the whole plant. It has $\mathrm{R} f 0.58$ and a violet colour in $50 \%$ aqueous $\mathrm{H}_{2} \mathrm{SO}_{4}$. 
Essential oil analysis

Capillary GLC analysis

A Carlo Erba ICU 600 gas chromatograph equipped with FID, spectra physics integrator and DB1 fused silica capillary column $(15 \mathrm{~m} \times$ $0.317 \mathrm{~mm}$ i.d. $0.25 \mu \mathrm{m}$ film thickness) was employed. GLC condition: carrier gas $\mathrm{He}(2 \mathrm{ml} /$ min); detector temp. $300^{\circ} \mathrm{C}$; injector temp. $250{ }^{\circ} \mathrm{C}$; oven temp. programme, initial temp. $50^{\circ} \mathrm{C} 4 \mathrm{~min}$ isothermal, $50-90{ }^{\circ} \mathrm{C} 4{ }^{\circ} \mathrm{C} / \mathrm{min} .90-300{ }^{\circ} \mathrm{C} 10{ }^{\circ} \mathrm{C} /$ $\mathrm{min}$, the $10 \mathrm{~min}$. isothermal. A $2 \mathrm{mg}$ portion of each oil was dissolved in $1 \mathrm{ml}$ ethylacetate and $1 \mu \mathrm{l}$ volume was injected. Retention index (RI): Kovats indices (Kovats, 1958) were calculated with respect to a set of co-injected even number hydrocarbons (C9 - C24). Each RI was subjected to library search by comparison with references RI and MS. Percentage of the identified compounds were computed from GLC peak areas. Total oil was set at $100 \%$.

\section{GLC-MS analysis}

A Carlo Erba HRGC 4160 gas chromatograph equipped with OV1 capillary column $(30 \mathrm{~m}$, $0.25 \mathrm{~mm}$ i.d., $0.25 \mu \mathrm{m}$ film thickness) coupled to a quadrupole mass spectrometer Finnigan MAT 4500 was employed for oil analysis. EI-mass spectra were recorded at $45 \mathrm{eV}$. Condition: injector $250{ }^{\circ} \mathrm{C}$; temp. programme $46^{\circ} \mathrm{C} 4$ min isothermal; $46-100{ }^{\circ} \mathrm{C}$ at $4{ }^{\circ} \mathrm{C} / \mathrm{min}$; $100-300^{\circ} \mathrm{C}$ at $8{ }^{\circ} \mathrm{C} /$ min. then $10 \mathrm{~min}$ isothermal; split ratio 1: 20 ; carrier gas $\mathrm{He} 50 \mathrm{kPa}$. Identification of the constituents was performed by computer library search, retention indices and visual interpretation of mass spectra with those found in the literature (ElShazly 1999; Adams 1995; Asres et al., 1998, Masada 1967; Ryhage and Sydow 1963; Sydow 1963). The identified compounds are recorded in Table I. The compounds are listed in order of elution from a DB1 and OV1 capillary columns.

\section{NMR measurements}

${ }^{1} \mathrm{H}$ - and ${ }^{13} \mathrm{C}$ NMR spectra were recorded on Ac Bruker Instrument in $\mathrm{CD}_{3} \mathrm{OD}$ at 300 and $75 \mathrm{MHz}$, respectively. EIMS was carried out on JEOL (Japan), $70 \mathrm{eV}$ direct inlet.

Compound (35): colourless oil, changed by time to dark brown then black, RI 1751, EIMS, $m / z$ (rel. int.) $\left[\mathrm{M}^{+}\right] 232$ (100), 217 (8), 199 (10), 189 (5), 175 (11), 161 (8), 147 (12), 135 (8), 124 (7), 119 (10), 109 (16), 108 (20), 95 (6), 91 (9), 79 (8), 77 (6), 55 (4), 43 (3), 41 (5). ${ }^{1} \mathrm{H}-\mathrm{NMR}\left(\mathrm{CD}_{3} \mathrm{OD}\right.$ at $300 \mathrm{MHz}) \delta 3.08(1 \mathrm{H}, \mathrm{d}, J=4.5 \mathrm{~Hz}, \mathrm{H}-1), 1.86$ (1H, m, H-2), 1.95 (1H, m, H-2), 1.33 (1H, m, H3), $1.73(1 \mathrm{H}, \mathrm{m}, \mathrm{H}-3), 1.48(1 \mathrm{H}, \mathrm{m}, \mathrm{H}-4), 2.12(1 \mathrm{H}$, d, $J=16.2 \mathrm{~Hz}, \mathrm{H}-6), 2.68(1 \mathrm{H}, \mathrm{d}, J=16.2 \mathrm{~Hz}, \mathrm{H}-$ 6), $2.19(1 \mathrm{H}, \mathrm{d}, J=16.8 \mathrm{~Hz}, \mathrm{H}-9), 2.98(1 \mathrm{H}, \mathrm{d}, J=$ $16.8 \mathrm{~Hz}, \mathrm{H}-9), 7.06$ (1H, q, $J=1 \mathrm{~Hz}, \mathrm{H}-12), 1.88$ $(3 \mathrm{H}, \delta, J=1 \mathrm{~Hz}, \mathrm{H}-13), 1.07$ (3H, s, H -14), 1.09 $(3 \mathrm{H}, \mathrm{d}, J=5.5 \mathrm{~Hz}, \mathrm{H}-15) .{ }^{13} \mathrm{C}-\mathrm{NMR}\left(\mathrm{CD}_{3} \mathrm{OD}\right.$ at $75 \mathrm{MHz}) \delta 64.48$ (d, C-1), 22.15 (t, C-2), 25.30 (t, C-3), 39.19 (d, C-4), 36.36 (s, C-5), 33.89 (t, C-6), 120.85 (s, C-7), 147.49 (s, C-8), 31.88 (t, C-9), 64.88 (s, C-10), 117.57 (s, C-11), 139.19 (d, C-12), 8.07 (q, C-13), 21.13 (q, C-14), 16.25 (q, C-15). Assignments were aided by DEPT, ${ }^{1} \mathrm{H}-{ }^{13} \mathrm{C}$ - COSY experiments.

\section{Screening for antimicrobial activity}

Tested microorganisms were Staphylococcus aureus, Bacillus subtilis (Gram positive bacteria); Escherichia coli, Klebsiella pneumoniae (Gram negative bacteria); Candida albicans (yeast) and Aspergillus flavus (fungi). The microorganisms were obtained from the stock cultures of the Department of Microbiology, Faculty of Pharmacy, Zagazig University. Antimicrobial activity was assayed via agar diffusion method. Small cups were taken out of the agar which could take approximately $60 \mu \mathrm{l}$ of oil solutions. Each cup was filled accurately with $50 \mu \mathrm{l}$ of oil solutions (20 mg oil was dissolved in $1 \mathrm{ml}$ dimethylformamide, DMF), as well as DMF as a control. The plates were incubated overnight at $37^{\circ} \mathrm{C}$ for bacteria and $30^{\circ} \mathrm{C}$ for fungi. The observed zones of inhibition were measured (in $\mathrm{mm}$ ) and compared against standard antibiotics. Results are recorded in Table II.

\section{Results and Discussion}

A quantitative and qualitative variation between the oils from leaves, flowers, stems and roots was apparent. All oils obtained smell smokelike, while the odour of intact plant is herbaceous and fruity. The oils have a pale yellow colour which changed by time to dark black.

Table I shows retention indices and relative percentages of the oil constituents. A total of 33 com- 
Table I. Chemical profiles of flower, leaf, stem and root essential oils of Senecio aegyptius var discoideus.

\begin{tabular}{|c|c|c|c|c|c|}
\hline \multirow[t]{2}{*}{ Compound } & \multirow[t]{2}{*}{$R I^{*}$} & \multicolumn{4}{|c|}{ Abundance ** } \\
\hline & & flowers & leaves & stems & roots \\
\hline 1 1-Nonane & 890 & 17 & 22 & 19 & $\operatorname{tr}$ \\
\hline $2 \alpha$-Thujene & 919 & $\operatorname{tr}$ & $\operatorname{tr}$ & $\operatorname{tr}$ & - \\
\hline $3 \alpha$-Pinene & 924 & 2.1 & 0.7 & 4 & $\operatorname{tr}$ \\
\hline 4 Sabinene & 959 & 1.8 & 0.6 & 1.5 & $\operatorname{tr}$ \\
\hline $5 \quad \beta$-Pinene & 961 & 1.5 & 0.2 & 3.9 & $\operatorname{tr}$ \\
\hline 6 Myrcene & 981 & 8.9 & 3.4 & 10.6 & - \\
\hline 7 1-Decene & 988 & $\operatorname{tr}$ & $\operatorname{tr}$ & $\operatorname{tr}$ & - \\
\hline $8 \quad \alpha$-Terpinene & 1004 & 0.3 & $\operatorname{tr}$ & 0.3 & - \\
\hline 9 p-Cymene & 1008 & $\operatorname{tr}$ & 0.2 & $\operatorname{tr}$ & - \\
\hline $10 \beta$-Phellandrene & 1014 & 3.7 & 0.5 & 3.8 & - \\
\hline 11 Limonene & 1018 & 0.4 & $\operatorname{tr}$ & 3.6 & - \\
\hline $12 Z(\beta)$-Ocimene & 1029 & $\operatorname{tr}$ & $\operatorname{tr}$ & $\operatorname{tr}$ & - \\
\hline $13 E(\beta)$-Ocimene & 1041 & $\operatorname{tr}$ & $\operatorname{tr}$ & $\operatorname{tr}$ & - \\
\hline 14 1-Nónen-3-ol & 1072 & $\operatorname{tr}$ & $\operatorname{tr}$ & $\operatorname{tr}$ & - \\
\hline 15 Terpinolene & 1078 & $\operatorname{tr}$ & $\operatorname{tr}$ & $\operatorname{tr}$ & - \\
\hline $16 \alpha$-Pinene oxide & 1085 & $\operatorname{tr}$ & $\operatorname{tr}$ & 0.4 & - \\
\hline 17 1-Undecene & 1090 & 0.3 & 0.3 & 0.7 & - \\
\hline 18 Octen-1-ol acetate & 1097 & $\operatorname{tr}$ & $\operatorname{tr}$ & $\operatorname{tr}$ & - \\
\hline 19 Sabina ketone & 1151 & $\operatorname{tr}$ & $\operatorname{tr}$ & $\operatorname{tr}$ & - \\
\hline 20 Terpin-4-ol & 1157 & $\operatorname{tr}$ & $\operatorname{tr}$ & $\operatorname{tr}$ & - \\
\hline 21 Methyl salicylate & 1166 & $\operatorname{tr}$ & $\operatorname{tr}$ & $\operatorname{tr}$ & - \\
\hline $22 \alpha$-Terpineol & 1170 & $\operatorname{tr}$ & $\operatorname{tr}$ & $\operatorname{tr}$ & - \\
\hline 23 Dihydromyrcenol & 1195 & 0.8 & 0.5 & 1.1 & - \\
\hline 24 Nordavanone & 1214 & $\operatorname{tr}$ & $\operatorname{tr}$ & $\operatorname{tr}$ & - \\
\hline 25 Dihyro-linalool acetate & 1262 & $\operatorname{tr}$ & $\operatorname{tr}$ & $\operatorname{tr}$ & - \\
\hline $26 \beta$-Elemene & 1381 & 0.8 & 0.3 & 0.3 & 4.2 \\
\hline 27 E-Caryophyllene & 1411 & 2.3 & 0.9 & 1.0 & $\operatorname{tr}$ \\
\hline $28 \alpha$-Humelene & 1444 & 0.6 & 0.4 & 0.7 & 0.6 \\
\hline 29 (E) $\beta$-Farnesene & 1448 & $\operatorname{tr}$ & $\operatorname{tr}$ & $\operatorname{tr}$ & $\operatorname{tr}$ \\
\hline 30 Drima-7,9-(11)-diene & 1461 & $\operatorname{tr}$ & $\operatorname{tr}$ & $\operatorname{tr}$ & 19.0 \\
\hline $31 \beta$-Chamigrene & 1468 & $\operatorname{tr}$ & $\operatorname{tr}$ & $\operatorname{tr}$ & $\operatorname{tr}$ \\
\hline 32 Valencene & 1483 & 0.2 & 0.1 & 0.1 & 3.4 \\
\hline 33 Butylatehydroxy toluene & 1499 & 0.2 & $\operatorname{tr}$ & $\operatorname{tr}$ & $\operatorname{tr}$ \\
\hline 34 Unidentified & 1674 & 2.3 & 2.5 & 1.4 & 1.8 \\
\hline 35 1,10-epoxyfuranoeremophilane & 1751 & 55.3 & 66.3 & 46.4 & 69.0 \\
\hline 36 Unidentified & 1842 & 0.6 & 0.7 & 0.4 & $\operatorname{tr}$ \\
\hline 37 Unidentified & 1919 & 0.1 & 0.1 & $\operatorname{tr}$ & $\operatorname{tr}$ \\
\hline
\end{tabular}

* Measured linear retention indices on an OV1 column; ** Area \%; $\operatorname{tr}=$ trace amounts $(<0.1)$.

Mass spectra of unknown compounds;

(34) GLC-EIMS, m/z (rel. int.) $\left[\mathrm{M}^{+}\right] 232$ (2), 214 (100), 199 (75), 185 (13), 171 (18), 155 (10), 141 (14), 128 (15), 115 (14), 91 (10), 77 (8), 67 (5), 55 (5), 43 (10).

(36) GLC-EIMS, m/z (rel. int.) [M+] 232 (100), 217 (17), 199 (45), 189 (5), 175 (21), 161 (6), 159 (6), 147 (31), 133 (13), 119 (14), 108 (25), 91 (14), 85 (11), 79 (14), 67 (8), 55 (11), 43 (11), 41 (11).

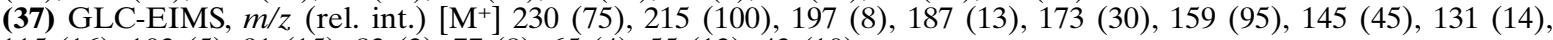
115 (16), 103 (5), 91 (15), 83 (3), 77 (8), 65 (4), 55 (13), 43 (10).

ponents were unambiguously identified by comparing their specific retention indices and mass fragmentations with those reported in literature. In addition three unidentified compounds (34, 36 and 37) were found that occurred only in small or trace amounts. The chemical composition of the flower, leaf and stem oils shows quantitative rather than qualitative variation. The root oil was devoid of monoterpene hydrocarbons (except traces of $\alpha$-pinene, $\beta$-pinene and sabinene) and oxygenated monoterpenes whereas sesquiterpene hydrocarbons and furanoeremophilan were abundant.

Compound 35, the major component, was isolated by PLC. The mass spectrum shows a $\mathrm{M}^{+}$at $m / z, 232$ suggesting a molecular formula $\mathrm{C}_{15} \mathrm{H}_{20} \mathrm{O}_{2}$. 
This formula indicates a sesquiterpene with 6 degrees of unsaturation and/ or double bonds; this was confirmed by the presence of 15 different carbons and 20 protons $\left(3 \mathrm{CH}_{3}, 4 \mathrm{CH}_{2}, 3 \mathrm{CH}, 5\right.$ quaternary carbons) in the ${ }^{13} \mathrm{C}$ and APT spectra and the ${ }^{1} \mathrm{H}$ NMR spectrum. A prominent peak at $\mathrm{m} / \mathrm{z}$ $108(20 \%)$ is typical for 3-methylfuranoeremophilan (Bohlmann, et al., 1979; Bohlmann and Zdero, 1974) or 3-methylligularan (Schild, 1971) resulting from Retro Diel's Alder (RDA) fragmentation, or the cleavage of bonds $\beta$ to the ring system in alkylfurans (Budzikiewicz, 1964). A fragment at $m /$ $z 217(8 \%)$ for $\mathrm{M}^{+}-\mathrm{CH}_{3}$ and the ion peak at $\mathrm{m} / z$ $199(10 \%)$ is for $\mathrm{M}^{+}-\mathrm{CH}_{3}-\mathrm{H}_{2} \mathrm{O}$. The latter fragment can be attributed to the ion $(\mathbf{X})$ in Scheme 1. This fragmentation implies an oxyran ring at ring $\mathrm{C}$ at the junction with ring $\mathrm{B}$ in $\mathbf{3 5}$. Fragment at $m / z, 124(7 \%)$ for $\mathrm{C}_{8} \mathrm{H}_{12} \mathrm{O}$ can be attributed to ions from $\mathrm{M}^{+}-108$ from RDA fragmentation; a prominent fragment at $m / z 109(16 \%)$ can derive from 124-Me. The ${ }^{1} \mathrm{H}$ NMR spectrum showed the presence of three methyl groups, one of which at $\delta 1.88$ $\left(\mathrm{d},{ }^{4} \mathrm{~J}=1 \mathrm{~Hz}\right)$ is vinylic on a quaternary carbon; was placed on position 11 on biosynthetic reasoning and coupled with the only proton at $\delta 7.06\left(\mathrm{q},{ }^{4} \mathrm{~J}=\right.$ $1 \mathrm{~Hz}$ ) which confirms that the furan ring is $3,4,5$ trisubstituted; one at $\delta 1.09(\mathrm{~d}, J=5.5 \mathrm{~Hz})$ is on $s p 3$ methine carbon for $\mathrm{H}-15$ and the other at $\delta 1.07$ (s) is on sp3 quaternary carbon for $\mathrm{H}-14$. Four sp3 methylenes, two of which are isolated from each other since each is a simple AM system showing only large geminal coupling at $\delta 2.98\left(1 \mathrm{H}, \mathrm{d},{ }^{2} J=\right.$ $16.8), \delta 2.19\left(1 \mathrm{H}, \mathrm{d},{ }^{2} J=16.8\right)$ for $\mathrm{H}-9$ and at $\delta$ $2.68\left(1 \mathrm{H}, \mathrm{d},{ }^{2} J=16.2\right), \delta 2.12\left(1 \mathrm{H}, \mathrm{d},{ }^{2} J=16.2\right)$ for $\mathrm{H}-6$; each is vinylic to the side of the furan ring and the other side is sp3 quaternary carbons forming the six membered ring $\mathrm{B}$; the other two sp3 methylene at $\delta 1.95(1 \mathrm{H}, \mathrm{m}), \delta 1.86(1 \mathrm{H}, \mathrm{m})$ for $\mathrm{H}-$ 2 and $\delta 1.73(1 \mathrm{H}, \mathrm{m})$, and $\delta 1.33(1 \mathrm{H}, \mathrm{m})$ for $\mathrm{H}-3$ are adjacent to each other since each is a complex AB multiplet from geminal and vicinal couplings. Three methines two of which are sp3 at $\delta 3.08$ $(1 \mathrm{H}, \mathrm{d}, J=4.5 \mathrm{~Hz})$ for $\mathrm{H}-1$ on oxygenated carbon 1 , and at $\delta 1.48(1 \mathrm{H}, \mathrm{m})$ for $\mathrm{H}-4$ forming ring $\mathrm{C}$; and one $s p 2$ at $87.06(1 \mathrm{H}, \mathrm{q}, J=1 \mathrm{~Hz})$. The ${ }^{13} \mathrm{C}$ spectrum showed the presence of five quaternary carbons two of which are sp3 at $\delta 64.88$ for oxygenated carbon, $\delta 36.36$ for $\mathrm{C}-5$ and three are sp2 carbons at $\delta 147.49,120.85$, and 117.60 . A one sp2 methine at $\delta 139.19$ typical of trisubstituted furan moiety (Atta-ur-Rahmann and Ahmad, 1992). The presence of 2 carbons at $\delta 64.88$ (s) and at $\delta 64.48$ (d) confirm the presence of oxirane ring. These data implicate the structural formula $\mathbf{3 5}$ as 1,10-epoxyfuranoeremophilan. 8,8a-epoxy-furanoligularan (35C) (= 8,8a-Epoxy3,4a,5-trimethyl-4,4a,5,6,7,8,8a,9-octahydronaphtho[2,3-b]furan (Schild, 1971) clearly differed from 35 indicating a different stereochemistry for 35. Also, matching the spectral data with those reported for compounds 35A and 35B identified before (Bohlmann, 1979) showed a clear and significant differ-

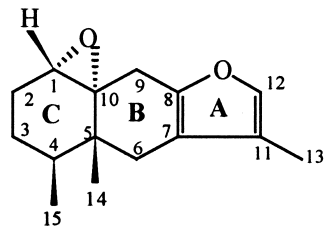

(35A)

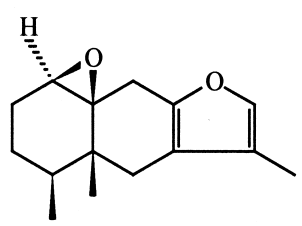

(35B)



(35C)

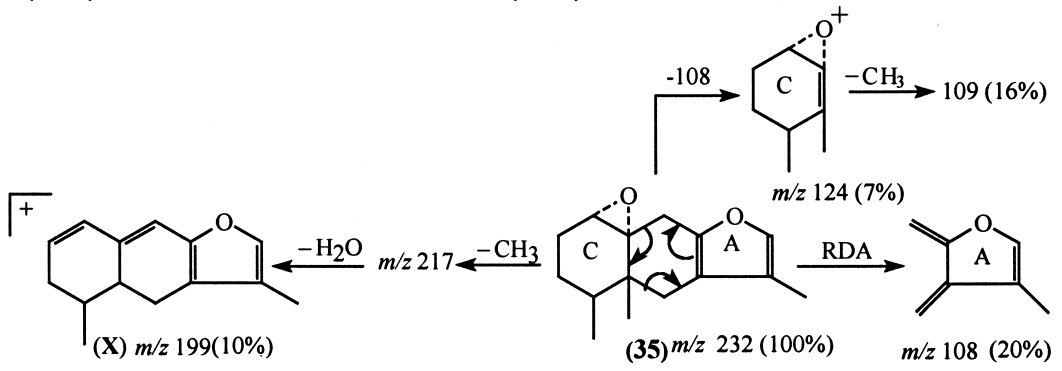

Scheme 1. 
ences with 35A except $\mathrm{C}-1$ resonance ( $\delta 63.4$ in $\mathrm{CDCl}_{3}$ for $\mathbf{3 5} \mathbf{A}$ as reported by Bohlmann vs. $\delta$ 63.28 in $\mathrm{CDCl}_{3}$ and 64.49 in $\mathrm{CD}_{3} \mathrm{OD}$ in our measurements) and complete agreement with 35B except C-1 resonance ( $\delta 59.0$ for $\mathbf{3 5 B}$ as reported by Bohlmann vs. 63.28 for our's). Assuming that the reported data are valid, our compound would be new albeit with the same structural formula as 35A, 35B or 35C, but with different stereochemistry. But, if the reported data (Bohlmann, 1979) misplaced C-1 resonance for compounds $\mathbf{3 5 A}$ and 35B , our compound would be the same as $\mathbf{3 5 B}$ and it would be the first time to be reported as volatile component in a volatile oil (Adams, 1995).

\section{Antimicrobial activity}

Flower and leaf volatile oils of $S$. aegyptius var. discoideus (Table II) showed significant level of antifungal activity against $C$. albicans, moderate effect against Gram positive bacteria, however, it has weak activity against Gram-negative bacteria. The isolated sesquiterpene (1,10-epoxyfuranoeremophilane) exhibited marked inhibition activity against Gram negative bacteria, Bacillus subtilis and fungi whereas no effect against Staphylococcus aureus.

\section{Acknowledgements}

Thanks are due to Dr. G. Schilling (Universität Heidelberg) for carrying out NMR measurements, Dr. A. Tei for GLC-MS (IPB HD) measurements, Dr. H. Abdel Salam (University of Zagazig) for his help in performing the antimicrobial tests and Dr. H. Abdel Baset for plant identification.

Table II. Results of antimicrobial screening of volatile oils of Senecio aegyptius var. discoideus.

\begin{tabular}{|c|c|c|c|c|c|c|}
\hline \multirow[t]{3}{*}{ Oils* and controls } & \multicolumn{6}{|c|}{ Diameter of inhibition zone in $\mathrm{mm}$. } \\
\hline & \multicolumn{2}{|c|}{ Gram - bacteria } & \multicolumn{2}{|c|}{ Gram + bacteria } & \multicolumn{2}{|c|}{ Fungi } \\
\hline & E. coli & K. pneumoniae & S. aureus & B. subtilis & C. albicans & A. flavus \\
\hline Tetracycline $30 \mu \mathrm{g} / \mathrm{disc}$ & - & 9 & 8 & 16 & - & - \\
\hline Chloramphenicol $30 \mu \mathrm{g} / \mathrm{disc}$ & 15 & 15 & 20 & 15 & - & - \\
\hline Penicillin $10 \mu \mathrm{g} / \mathrm{disc}$ & - & - & 22 & - & - & - \\
\hline Gentamycin $10 \mu \mathrm{g} / \mathrm{disc}$ & - & 18 & 12 & 25 & - & - \\
\hline Nystatin $30 \mu \mathrm{g} / \mathrm{disc}$ & - & - & - & - & 15 & 10 \\
\hline Volatile oil of flowers & 7 & 3 & 10 & 7 & 16 & 8 \\
\hline Volatile oil of leaves & 8 & 3 & 8 & 9 & 20 & 6 \\
\hline 1,10-epoxyfuranoeremophilane & 16 & 17 & - & 25 & 29 & 20 \\
\hline
\end{tabular}

\footnotetext{
* All assays consisted of $50 \mu \mathrm{l}$ of a test solution, containing $20 \mathrm{mg}$ oil in $1 \mathrm{ml} \mathrm{DMF}$; - = no inhibition.
} 
Adams R. P., (1995), Identification of Essential Oil Components by Gas Chromatography / Mass Spectrometry. Allured Publ. Corp., Carol Stream, Illinois USA.

Asres K., Tei A., Moges G., Sporer F. and Wink M. (1998), Terpenoid composition of the wound-induced bark exudate of Commiphora tenuis from Ethiopia. Planta Med., 64, 473-475.

Atta-ur-Rahman and Ahmad V. U. (1992), ${ }^{13} \mathrm{C}-\mathrm{NMR}$ of Natural Products. Vol. 1, Monoterpenes and Sesquiterpenes. Plenum Press. New York and London.

Bohlmann F. and Zdero C. (1974), Über neue Sesquiterpene der Gattung Senecio. Chem. Ber. 107, 29122922.

Bohlmann, F., Knoll K. H., Zedro C., Mahanto P. K. Grenz M., Suwita A., Ehlers D., Le Van N., Abraham W. R. and Natu A. A. (1977), Terpen-Derivate aus $S e$ necio Arten. Phytochemistry 16, 965-985.

Bohlmann F., Zdero C., Berger D., Suwita A., Mahanta P. and Jeffrey C. (1979), Neue Furanoeremophilane und weitere Inhaltstoffe aus südafrikanischen Senecio-Arten. Phytochemistry 18, 79-93.

Budzikiewicz, H., Djerassi, C. and Williams, D. H. (1964), Structure Elucidation of Natural Products by Mass Spectrometry. Holden-Day, INC, San Francisco, London \& Amsterdam, Vol. II PP. 151.

De Pooter H. L., De Buyck L.F., Schamp N. M., Aboutabl E. A., De Bruyn A. and Husain S. Z. (1986), The volatile fraction of Senecio glaucus subsp. coronopifolius. Flavour Fragrance J. 1, 159-163.

Egyptian Pharmacopoeia (1984), General Organization for Governmental Printing Affairs. Cario, p 31.

El-Shazly A. M. (1999), Essential oil composition of $\mathrm{Se}$ necio desfontainei Druce (Compositae). Zagazig J. Pharm. Sci., 8, 1-8.

Grace M. H. and Khattab A. M. (1998), Chemical constituents and molluscicidal activity of Senecio cineraria D. C. Egypt. J. Pharm. Sci. 39, 253-266.
Hartmann T. and Witte L. (1995), Chemistry, biology and chemecology of pyrrolizidine alkaloids. In: Alkaloids: Chemical and Biological Perspective (Pelletier S. W., ed., ). Pergamon, Oxford, Vol. 9, pp. 155- 233.

Kovats E. (1958), Gas-Chromatographische Charakterisierung organischer Verbindungen. Teil I: RetentionsIndices aliphatischer Halogenide, Alkaloide, Aldehyde und Ketone. Helv. Chim. Acta 41, 1915-1932.

Masada Y., (1967), Analysis of Essential Oils by Gas Chromatography and Mass Spectrometry. Wiley, New York, NY.

Mangi N., Garg S. N., Agarwal S. K. and Mathela C. S. (1995), The occurrence of $\beta$-thujone and a new $p$ menthane derivative in Senecio chrysanthenemoides leaf oil. J. Ess. Oil Res. 7, 511-514.

Mitsuo M., Nobutaka H. and Kameoka (1979), Koen Yoshishu-Koryo, Terpen oyobi Seiyu Kagaku ni Kansuru Toronkai, 23 rd. 51. Symposium on the chemistry of terpenes, essential oils and aromatics.

Nordenstam, B. (1977), The Biology and Chemistry of the Compositae. Heywood, V. H., Harborne J. B. and Turner B. L., eds.). Academic Press INC London, pp. 799-830.

Ryhage R. and Sydow E. V., (1963), Mass spectrometry of terpenes. I. Monoterpene hydrocarbons. Acta Chem. Scand., 17, 2025-2035.

Schild W. (1971), 8,8a-Epoxy-furanoligularan, ein neues Furanosesquiterpen aus Senecio silvaticus L. Tetrahedron. 27, 5735-5739.

Sydow E. V., (1963), Mass spectrometry of terpenes. II. Monoterpene alcohol. Acta Chem. Scand., 17, 25042512.

Van Dooren B., Bos R. and Tattje D. H. E. (1981), Composition of essential oils of some Senecio species. Planta Med., 42, 385-389.

Yamaguchi, K. (1970), Spectral Data of Natural Products, Vol. I. Elsevier Publishing Company, Amsterdam, London \& New York. 